\title{
ANÁLISE DAS MANIFESTAÇÕES PATOLÓGICAS NA IGREJA DE NOSSA SENHORA DA PIEDADE DO PARAOPEBA USANDO TERMOGRAFIA
}

\author{
ANALISYS OFPATHOLOGICAL MANIFESTATIONSIN THEMOTHERCHURCHOFNOSSA SENHORA \\ DA PIEDADE DO PARAOPEBA USING THERMOGRAPHY
}

CYNARA FIEDLER BREMER, Dra.| UFMG

GLÁUCIA NOLASCO DE ALMEIDA MELLO, Dra. | PUC-MG

FERNANDA ISABELLA SOARES BERNARDES |PUC-MG

MARCELLA AMARAL RODRIGUES PINTO | PUC-MG

ALINE MARACAHIPE ROCHA | UFMG

\begin{abstract}
RESUMO
Quando é necessário investigar tanto a questão da durabilidade quanto a incidência de manifestações patológicas nos edifícios, geralmente são utilizados procedimentos não destrutivos para inferir causas, comportamentos e anomalias, além de identificar e mapear regiões de danos a estruturas e outros sistemas de prédios. Entre os vários métodos para a realização dos testes em questão, destaca-se a termografia. Descrita como termo genérico, a termografia é baseada em técnicas usadas para detectar a temperatura na superfície dos objetos, mapeando-os por meio da distribuição de temperatura de campo da imagem. Pode ser apresentado como um método não destrutivo de identificação visual do gradiente de temperatura da superfície de um corpo, sob condições ambientais, sem manter contato direto com ele. O presente trabalho teve como objetivo analisar as manifestações patológicas presentes em um edifício do século XIX, a lgreja Matriz de Nossa Senhora da Piedade do Paraopeba, localizada na cidade de Brumadinho, Minas Gerais, Brasil, com o auxílio de uma câmera termográfica. O uso dessa técnica foi efetivo, pois era uma propriedade listada pelo patrimônio histórico municipal, para o qual testes destrutivos não seriam recomendados.
\end{abstract}

PALAVRAS CHAVE: Manifestações patológicas; Herança; Teste não destrutivo; Termografia

\begin{abstract}
When it is necessary to investigate both the question of durability and the incidence of pathological manifestations in buildings, often non-destructive procedures are used to infer causes, behaviors and anomalies, as well as to identify and map regions of damage to structures and other systems of buildings. Among the various methods for carrying out the tests in question, thermography stands out. Described as a generic term, thermography is based on techniques used to detect the temperature on the surface of objects, mapping them through the field temperature distribution of the image. It can be presented as a non-destructive method of visual identification of the surface temperature gradient of a body, under ambient conditions without maintaining direct contact with it. The present paper had as objective to analyze the pathological manifestations present in a nineteenth century building, the Mother Church of Nossa Senhora da Piedade do Paraopeba, located in the city of Brumadinho, Minas Gerais, Brazil, with the aid of a thermographic camera. The use of this technique was effective since it was a property listed by municipal historical patrimony, for which destructive tests would not be recommended.
\end{abstract}

KEY WORDS: Pathological manifestations; Heritage; Non-destructive testing; Thermography 


\section{INTRODUCTION}

According to the National Historical and Artistic Heritage Institute (IPHAN), historical heritage can be defined as a good that presents meaning and expresses importance to society. Old buildings characterize the way of life and the customs of the society that lived there and are a representation of the historical context of the time. In order to preserve the identity of a city, region or people, it is necessary to encourage the preservation of its historical, cultural, natural, architectural and urban heritage.

Knowing the useful life and the deterioration curve of each material used in the historical building is necessary for the preservation and for the adoption of the necessary restorative measures (Barbosa et al. 2010). The oldest buildings were built with materials, techniques and typologies different from those used today, which were often used without previously established criteria that guaranteed quality and full useful life. Allied to this, the absence of maintenance could have promoted the appearance of pathological manifestation and made buildings unhealthy, besides interfering in the aesthetic aspect that characterizes their cultural identity.

According to Nóbrega (2017), one of the most frequent problems found in buildings is connected to humidity, since they are often difficult to solve, as well as expensive. In many cases, there are leaks and infiltrations, caused by deficiencies in hydraulic systems, waterproofing and laying and maintenance of coatings, which may lead to the development of cracks and crevice due to failures in the execution of the structural project.

The methods used to diagnose the deficiencies of a structure can be classified as destructive, semi destructive and non-destructive. Non-destructive test methods are non-invasive techniques used to determine the characteristics of the material examined. Unlike destructive methods, non-destructive methods allow the analysis of the object in question without harming or causing irreversible damage to the structure (Plesu et al., 2012).

The Brazilian Association of Non-Destructive Testing and Inspection describes Non-Destructive Testing (NDT) as techniques used to inspect materials and equipment without damaging them, which can perform in manufacturing, construction, assembly and / or maintenance stages. Among the non-destructive tests, thermography consists of an image recording technique used to detect the surface temperature of the objects and generate a full field temperature distribution image (Bucur, 2013).

Considering the importance of historical buildings and the possibility of evaluating them by means of non-destructive tests, the present paper had the objective of evaluating the pathological manifestations present in the Mother Church of Nossa Senhora da Piedade do Paraopeba, since the last church reform, built in the 19th century and located in the city of Brumadinho in Minas Gerais, Brazil.

To identify the pathological manifestations, the non-destructive thermography test was used. The images were captured by FLIR T450sc thermal imager. Concomitant with the photographic analysis and the visual inspection, the data collection was performed for a historical search of the interventions and modifications previously performed.

It was possible to identify some structural elements (beams) and also to identify regions with excess humidity with the aid of the thermographic camera, while visually cracks, fissures, paint displacement, vesicles and deteriorated pieces of wood were found.

\section{CHARACTERIZATION OF THE BUILT PATRIMONY}

Based in the district of Piedade do Paraopeba, municipality of Brumadinho, state of Minas Gerais, Brazil (Figure 1), the Mother Church of Nossa Senhora da Piedade do Paraopeba is a sumptuous architectural example representing the baroque colonialstyle to the region. The edification is a reference for the identity of the district, both because of its link to the daily life of the population and its history in the missionary-Jesuit period.

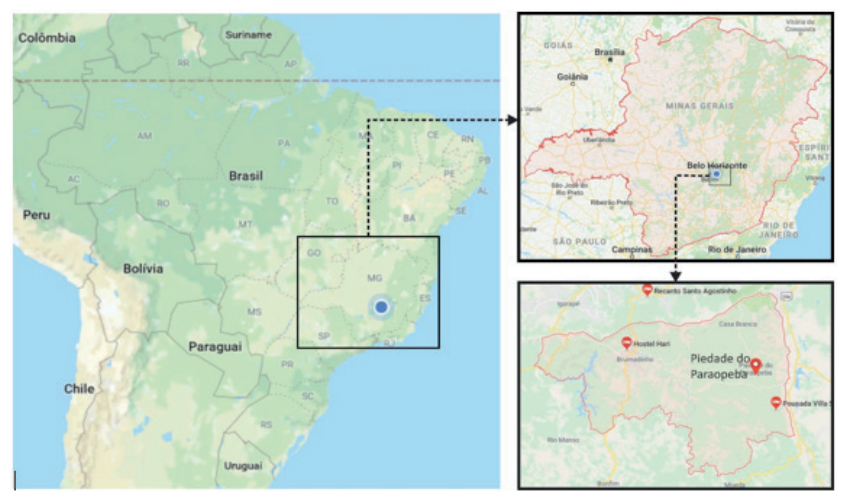

Figure 01 - Localization of the city of Piedade do Paraopeba, Brazil Source: Google Maps.

Piedade do Paraopeba was occupied by Bandeirantes Paulistas in the late seventeenth and early eighteenth centuries. According to historical research, the camp played an influential economic role for the Portuguese crown due to the exploitation of the gold mines. Before the Mother Church construction, it was erected near the place, at the end of the seventeenth century, a small chapel with thatch cover, dedicated to Our Lady of Mercy. This primitive 
hermitage, of simple construction, was rebuilt in 1713 and in 1729 by order of the bandeirante Bento Rodrigues. With this last reconstruction the chapel was enlarged having the divisions of nave and main chapel, with a main altar and two collateral ones, in rectangular plan and a sacristy at the back (Andrade, 2014). The new chapel was built with walls made of adobe and bricks, stalks of braunas, cobblestones running on wooden bars and curved ceramic roofs over wooden crates (Andrade, 2014).

Historical records show that the present Mother Church would have been built between the years of 1820 and 1830 by determination of three priests who resided in the town. The old chapel was gradually demolished and some of its materials were reused in the new building, such as the altars and part of the old arch-cross. Between the years of 1896 and 1907 the Church underwent its first reformation with enlargement and construction of the two bell towers and the "lateral corridors" - forming a late baroque typology, which referred to the old colonial matrixes, but which seemed outside the neoclassical / eclectic time (Andrade, 2014).

In the 1960s the Mother Church underwent a major renovation that changed the main characteristics of its constructive elements without, however, changing its typology.

Its external walls were redone in brick masonry with concrete structure. The original floor reused from the old chapel was replaced by hydraulic tile. The sacristy and the arch-cross were enlarged, the latter to improve the visibility of the chancel. Attachments were also built in the back (Andrade, 2014).

After this great reform and for more than a decade the mother church did not have a maintenance plan for its conservation. The result of this was the advanced state

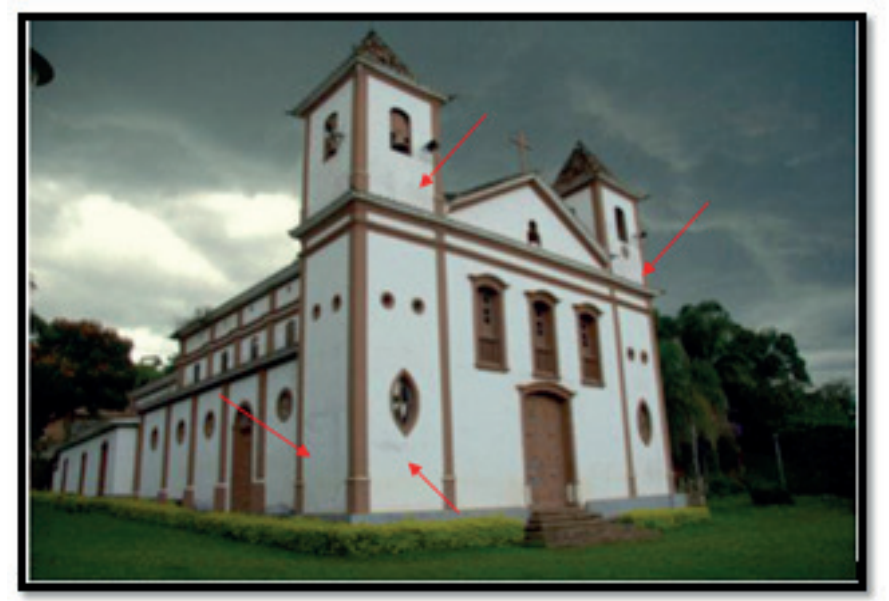

(a) of deterioration that lasted until 1976, when a new reform was initiated. Currently the church had as main pathological manifestations the attack of xylophagous insects on its wooden parts (frames and artistic elements) and structural problems in the nave, towers, side corridors and roofs. Some pathological problems reported at the time are present nowadays and are cause of great concern for the structural security of the church.

In the 1976 renovation the remainder of the adobe masonry was replaced by concrete structure and ceramic bricks. In fact, adobe remnants on one of the walls can be checked in situ. The wood from the roofs of the nave and the chancel, which had deteriorated, was replaced by slabs and beams of reinforced concrete. A new enlargement was made in the sacristy and in the back of the church, which received new frames (Andrade, 2014).

Twelve years later, in 1988, another reform took place in the church. This one contemplated the painting of the artistic elements, the gilding of the altars and the painting of the ceilings of the nave and the main chapel with religious elements. In 2003 ceramics were placed on the floor of hydraulic tiles of the nave, the corridors and the main chapel; the painting was redone both externally and internally; and a room was built on the side of the church to serve as a store for religious articles and external toilets. In Figures 2 and 3 it is possible to see the difference of colors from the windows and doors which are different from the present ones. It is also possible to notice the presence of pathological problems, which are still visible in the church nowadays, see Figure 2a. From 2007 until the present day the interventions that took place in the mother church were just simple repairs and internal and external painting.

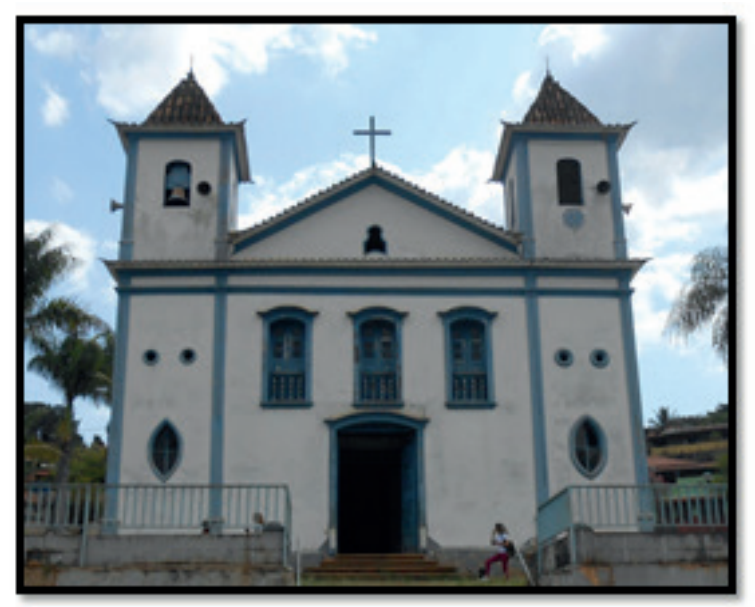

(b)

Figure 02 - Photo from the Mother Church of Nossa Senhora da Piedade do Paraopeba (a) in the beginning of 2000; (b) nowadays Source: Google and Authors 'collection. 


\section{VARIABLES THERMOGRAPHY}

Thermography is a non-destructive test method that relies on the ability of materials to emit energy in the form of heat. According to Pedra et al. (2016) and Plesu et al. (2012), all objects emit infrared radiation and the intensity of this radiation depends on the temperature of the object, the ability of the object to emit radiation (emissivity), thermal properties and physical properties such as porosity, density and humidity.

Grinzato (2012) claims that thermography is applied successfully since the 1960s, with various purposes. Among them, surface temperature mapping of buildings is an efficient method for the control of pathological manifestations, as well as its use in humans or animals, in electronic equipment and in cases of corrosion and fire. The use of the method in buildings allows obtaining information that is not possible visually, such as: the location of structural and non-structural elements, their shapes, the characteristics of the materials used and their state of conservation.

The thermography test uses a camera to detect and record the energy reflected by the elements. An infrared camera has specialized sensors to detect infrared radiation reflected by the surface of the object. For such reflection to occur it is necessary that the object is previously heated, passively or actively. In the passive method the material is subjected to heating by means of a natural source without artificial thermal stimulation. The configuration of the surface, its conditions and the environment in its surroundings influence the propagation in the heat and consequently in the measurement of the temperatures. In this method, the penetration and the distribution of the heat in the surface depends on the thermal properties of the material and its internal layers, being not affected by the ambient temperature (Spodek and Rosina, 2009; Plesu et al., 2012; Bauer and Pavón, 2015). According to Plesu et al. (2012), the heating medium used by the passive technique has a low cost and allows a uniform distribution of heat on large surfaces. The active method is often used in smaller and internal areas.

According to Meinlschimidt (2005), heat will dissipate at a rate corresponding to the thermal properties of the material, such as density, thermal capacity, thermal conductivity and bond quality between the top surface layer and the base material. Any defect present in the body produces a barrier during the process of diffusion of heat, so the temperature of the surface above the defect will decrease more slowly than the temperature in other regions. Detection of defects can take a few seconds, or even a few minutes or even hours after the impact of the heat, depending on the material, the depth of the defect and the heat intensity. Thus, the propagation of heat in a material is altered by the presence of anomalies, so thermography is used for the detection of building problems (Spodek and Rosina, 2009).

"It is necessary to know or determine several thermographic parameters, which are treated by the specific algorithms of the equipment, so as to have the appropriate accuracy of the temperatures presented in the thermogram" (Bauer and Pavón, 2015). There are several factors that influence the results of thermography, Plesu et al. (2012) divided them into three distinct categories: i) Climatic conditions such as ambient temperature, relative humidity, gas concentration, apparent reflected temperature, wind and insulation; ii) Characteristics of the element, such as emissivity, reflectivity, uniformity, surface coloring and finishing; iii) Characteristics of the environment such as viewing angle and distance and orientation of the building relative to the sun during the inspection.

In addition to the factors mentioned, it is also necessary to consider the variables related to thermographic equipment, such as focus, lens and geometric resolution, in order to determine the degree of detail of the inspection.

According to Spodek and Rosina (2009), emissivity is a parameter that has great influence in the thermography tests. It is a factor between 0 and 1 which indicates the ability of the material to radiate absorbed energy. Table 1 indicates the emissivity value for the most common building materials in construction.

Plesu et al. (2012) state that most of the materials used in the finishing of buildings have emissivity between 0.90 and 0.96 and therefore only one emissivity factor can be used for the evaluation of the thermographic properties of a building All these variables affect the quality of the results and their interpretation, so it is of fundamental importance that the operator of the equipment has knowledge of each one of them.

\begin{tabular}{|l|l|}
\hline Material & $\varepsilon$ \\
\hline Concrete & 0.94 \\
\hline Sand & 0.76 \\
\hline Gravel & $0.75 \ldots 0.80$ \\
\hline Plastic & $0.90 \ldots 0.96$ \\
\hline Glass & $0.90 \ldots 0.96$ \\
\hline Wood & $0.80 \ldots 0.90$ \\
\hline Ink & $0.90 \ldots 0.96$ \\
\hline
\end{tabular}

Table 01 - Emissivity coefficient of the main Construction Materials Source: Plesu et al. (2012). 


\section{METHODOLOGY}

For an analysis of the conditions and an identification of the pathological manifestations present in the Mother Church of Nossa Senhora da Piedade do Paraopeba, inspections were carried out with a presence of qualified professionals. This technique of passive thermography was chosen because, as it was a building with historical tipping, it was possible to perform an inspection and subsequent analysis of the results without any physical damage to the patrimony or alteration of its conservation status.

"The use of external energy sources on a coating, since there is no layer of protection, promotes a pathology in the historical work" (Cortizo, 2007). Thus, the choice for the passive technique was based on the least possible historical intervention, in order to avoid the additional thermal load of destructive processes.

The equipment used to capture the images was a FLIR camera, model T450 sc (Figure 3), resolution of $320 \times 240$ pixels, IFOV of $1.36 \mathrm{~m}$ rad, minimum focus distance of $0.4 \mathrm{~m} \pm 11^{\circ} \mathrm{C}\left( \pm 1.8^{\circ} \mathrm{F}\right)$ or $\pm 1 \%$ reading for a limited temperature range accuracy. The camera has a predefined temperature range, thus thermograms a single scale of nuclei, where the reddest region of the image corresponds to the higher temperatures and the bluish color to the lower temperatures.

The photographic series began in the afternoon after 2:00 p.m., as the church would have received heat evenly on most of its external walls, generating constant thermal contrast. The temperature conditions of the region were between $19{ }^{\circ} \mathrm{C}$ and $31^{\circ} \mathrm{C}$, and at the time of the photographic recording the temperature was approximately $26^{\circ} \mathrm{C}$ with relative humidity of $49 \%$.

Following the indications of the study by Alam et al. (2007), the images were not photographed with a standardization of distance or height of the camera, as this does not interfere in the thermographic result. In relation to the emissivity, the value of 0.95 was used, since there is greater precision in the reflective temperature and it is a value that serves the majority of materials, as stated by Plesu et al. (2012).

After the collection of information and images, the analysis was done to identify the probable pathological manifestations present in the building and their causes.
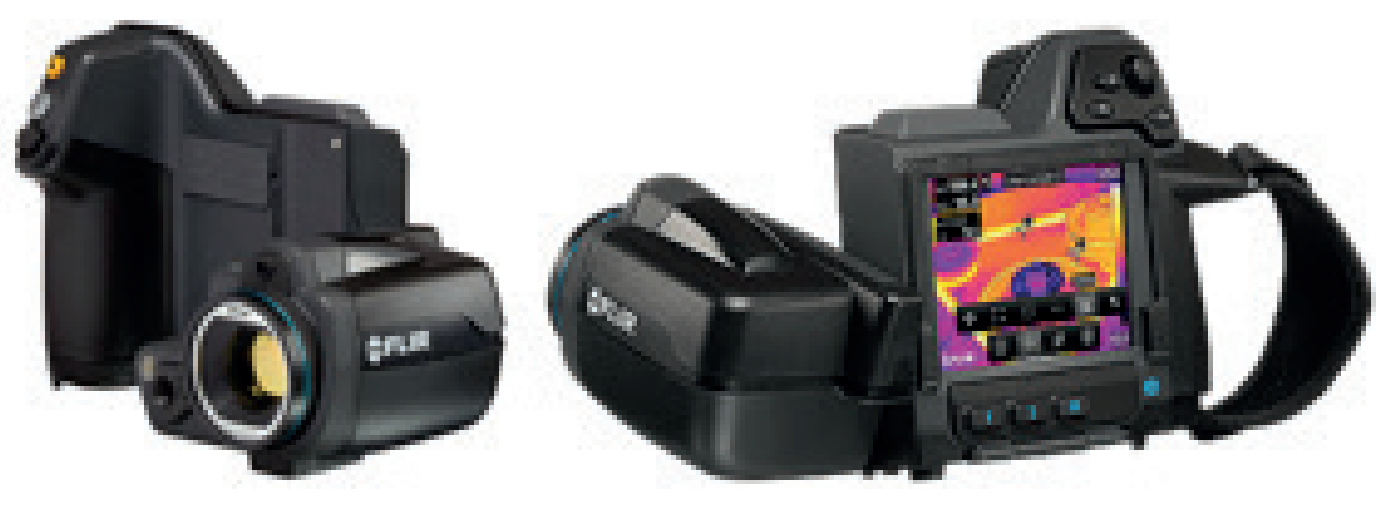

Figure 03 - FLIR 450sc termal imager Source: FLIR, 2016

\section{PRESENTATION AND ANALYSIS OF RESULTS}

The state of degradation of the church's structure is worsening every year. Cracks and gaps in the walls, infiltrations due to rising humidity and coming from the roof, painting detachment, plaster losses, structure reinforcement exposition, xylophagous insect attack, cracking and lack of ceramic flooring and displacement of plastering with exposure of the masonry were some of the pathological problems that were verified in the on-site visit occurred in November, 2017. Among the pathological manifestations verified, some were analyzed with the aid of the thermographic camera and are presented in this paper. As for the pathological manifestations, the analysis was performed considering both the visual inspection, photographically documented, and the thermographic documentation.

In historical buildings the main area of visual impact is the main façade. In the Church under study, the facade is preserved structurally, but it shows worn paint with bubbles, indicating infiltrations and lack of maintenance. The thermographic images, presented in Figure 4, presented several internal structural elements perceptible by the temperature difference and some points of infiltration.

Visually it was possible to observe the appearance of cracks in the edges of the lower oval windows, as indicated in Figure 5. The windows are points of concentration of tension, because as an old building, it probably did not have constructive elements that absorb such tensions and crack propagation. 


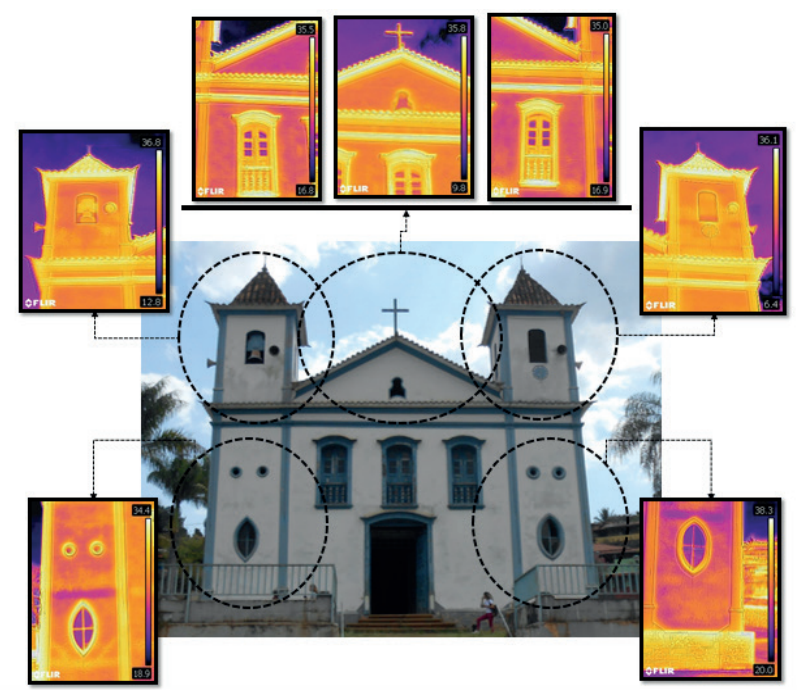

Figure 04 - Frontal facade of Mother Church of Nossa Senhora da Piedade do Paraopeba Source: Authors' collection.

On the sides of the historic building, it was notable the higher incidence of rising humidity perhaps due to the lack of waterproofing and the deterioration caused by it, causing aesthetic damages. There were several spots in the paint and the appearance of shells and bubbles indicated

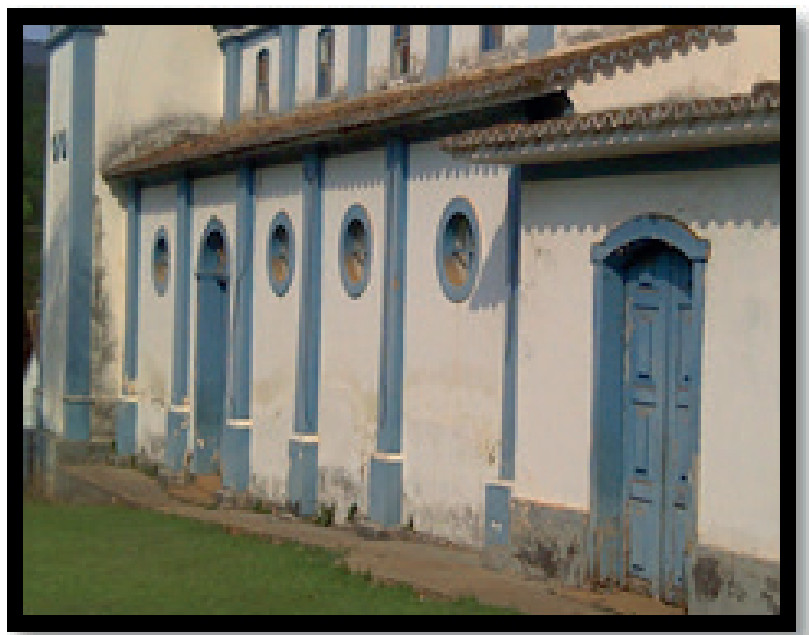

Figure 06 - Right side of the Mother Church of Nossa Senhora da Piedade do Paraopeba Source: Authors' collection.

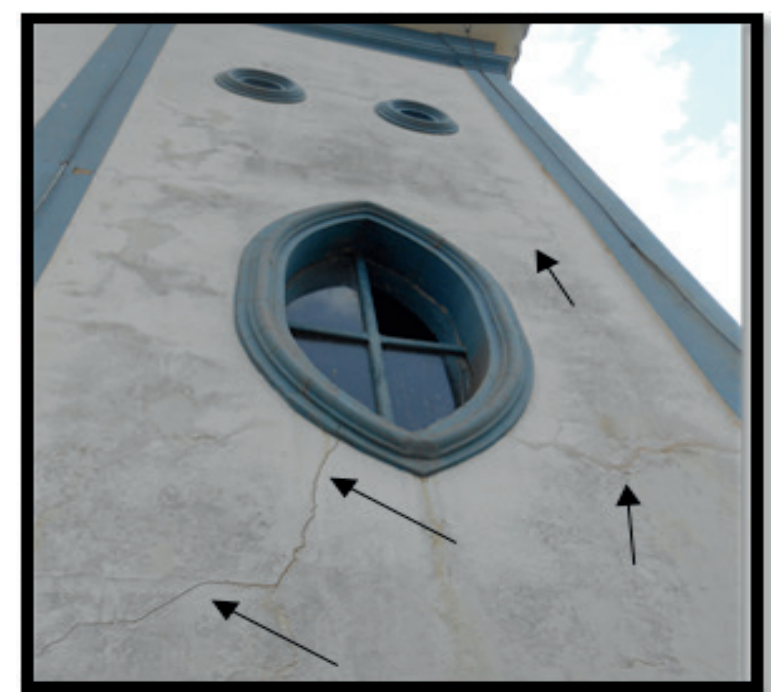

Figure 05 - Fissures identified visually on the facade Source: Authors' collection.

the action of water on the building. It is possible to visualize the effects of humidity on the right side of the building (see Figures 6 and 7) and on the left side (Figures 8 and 9). In Figures 7 and 8 it was identified the presence of bond beans. These doors were different from the others because they were constructed on the $60 \mathrm{~s}$, after the rest of the building.

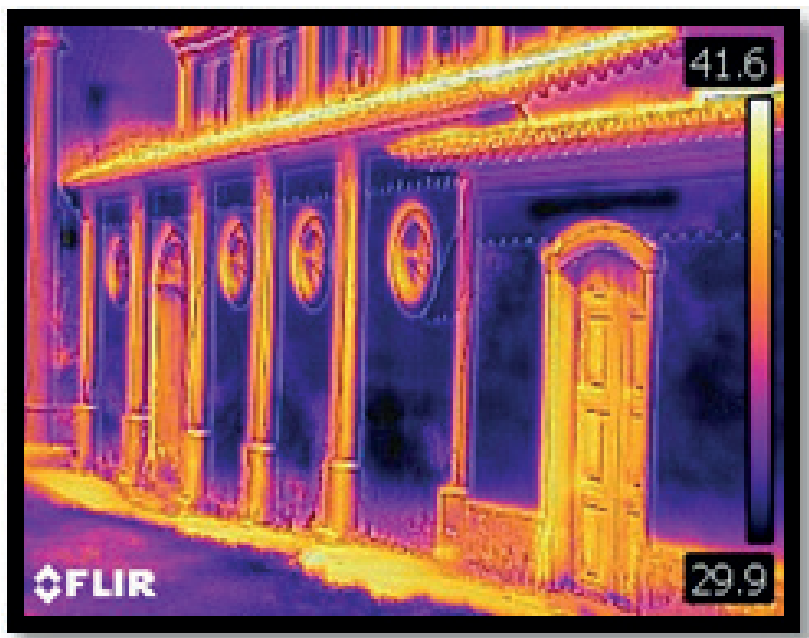



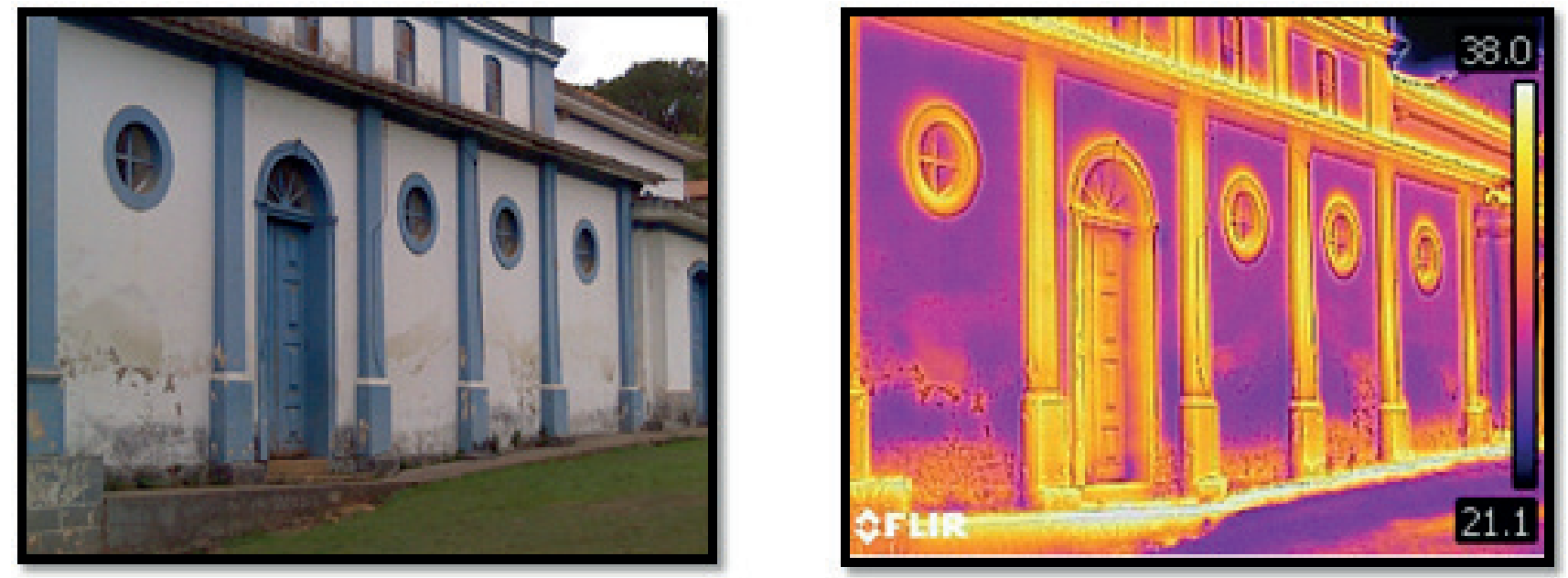

Figure 07 - Right side of the Mother Church of Nossa Senhora da Piedade do Paraopeba

Source: Authors' collection.
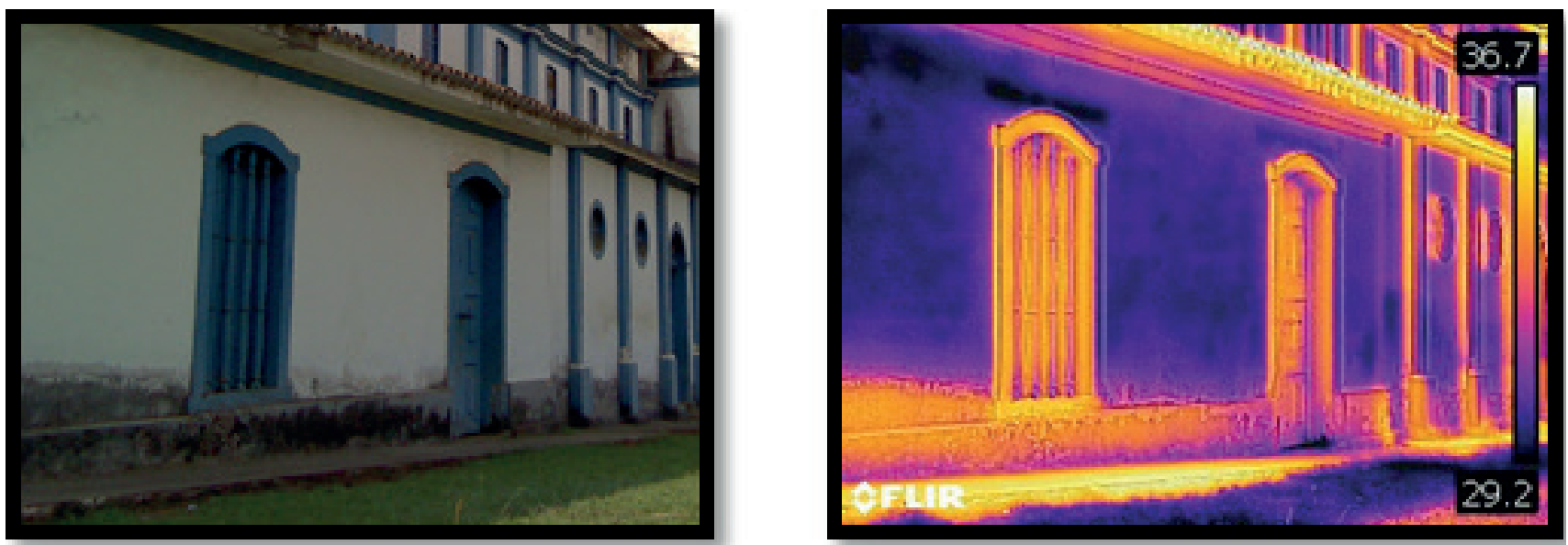

Figure 08 - Left side of the Mother Church of Nossa Senhora da Piedade do Paraopeba Source: Authors' collection.
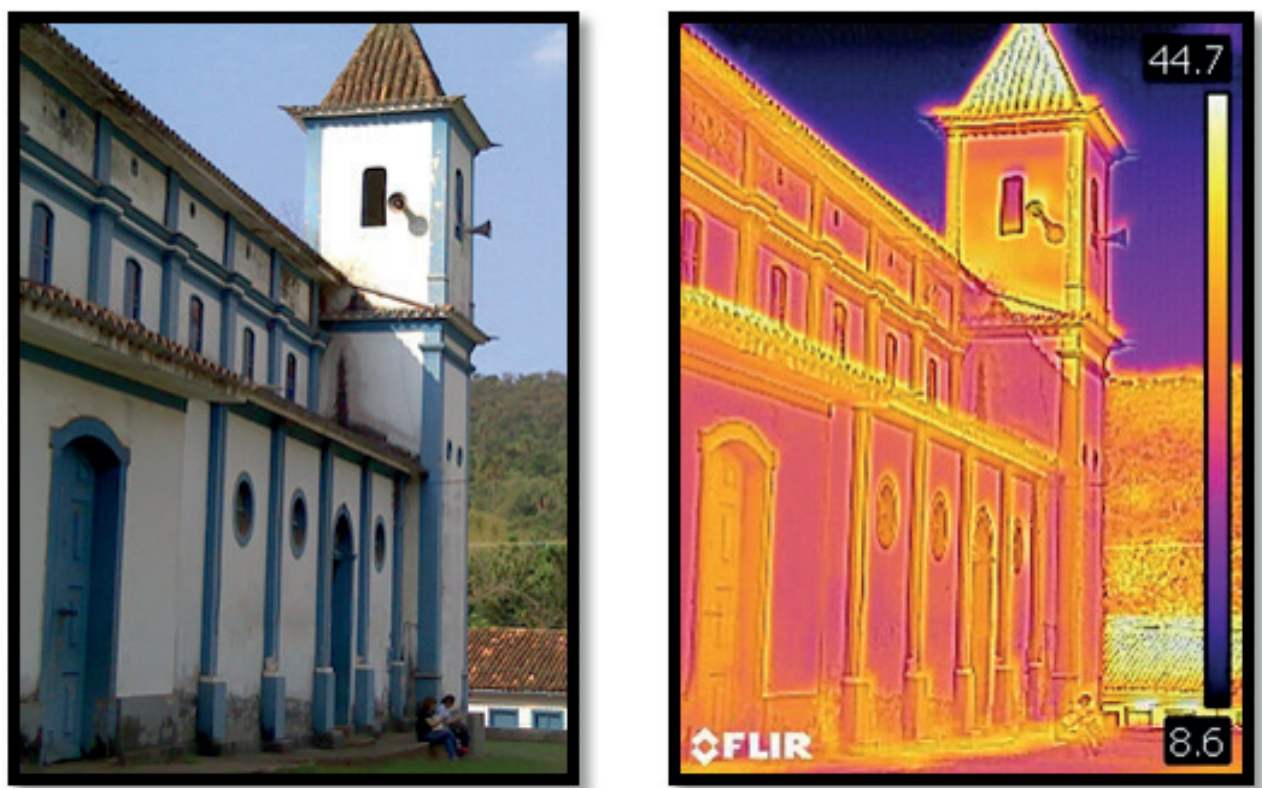

Figure 09 - Left side of the Mother Church of Nossa Senhora da Piedade do Paraopeba Source: Authors' collection. 
With the thermographic analysis it was possible to identify areas of concentration of internal moisture, as indicated in Figures 10 and 11. Souza (2008) affirms that the damages that are concentrated in the lower part of the walls are caused mainly because of humidity due to the proximity of the soil. The water present tends to infiltrate and to be absorbed capillary by the constituent materials up to a certain height.

It has been observed that moisture concentrates above degraded areas, this occurred maybe because the liquid evaporates more easily from the damaged surface, due to direct exposure to external heat. In addition, the walls were composed by permeable material, so the water diffuses by capillarity over an area larger than that visually apparent.

In addition to water absorbed by capillarity, rainwater damage was also identified, which, due to a probable deficiency in the water drainage system or even the damaged roof and displaced tiles, produced the same effect at high wall heights of sealing.

The towers of the building, since 2002, have serious structural problems, presenting considerable cracks, even with palliative actions of installing wooden beams in the baptistery to support the chorus and relieve the load of the external walls and towers - solution that remains (Andrade, 2014). The points representing cooler areas in Figure 12 may indicate the propagation of air and water in the structural element, since the tower has cracks that allow the entry of these natural components.

It was verified that the interior of the building has a smaller number of pathological manifestations. The structural part of the main arch and the slabs are preserved, as can be seen in Figures 13 and 14, so that they offer no significant risk or compromise to the aesthetics of the building.

The slabs of the lateral corridors, presented in Figures 15 and 16 , present painting problems, characterized by displacements and vesicles. Thermography indicated some regions of high temperature, which converge in a larger area, that by visual inspection had no wear near the lower surface. It is expected that such behavior occurs due to the lack of tiles or poor positioning of the tiles, allowing the entrance of sunlight and a higher incidence of heat or by the detachment of the substrate.

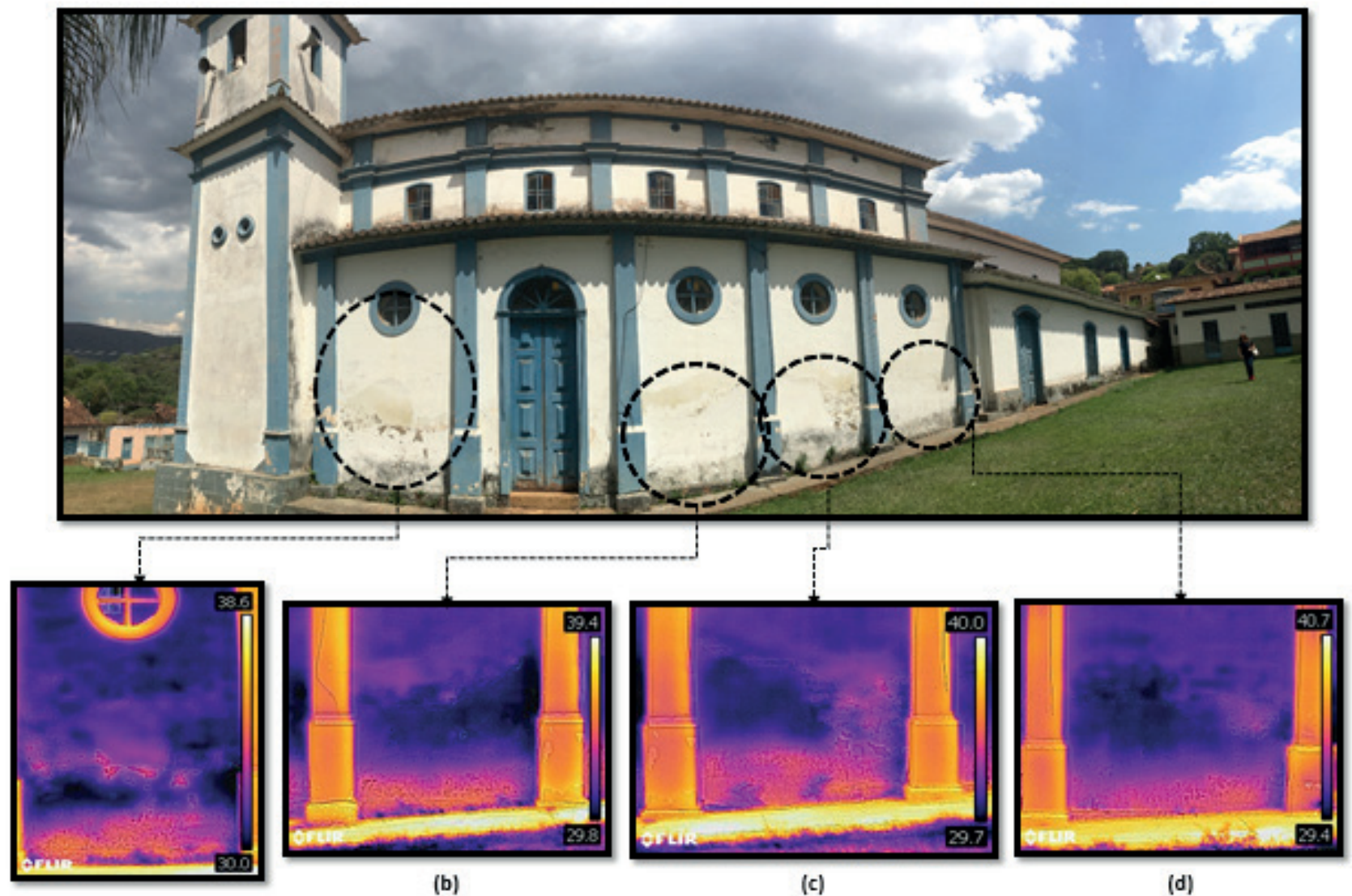

Figure 10 - Detail of moisture areas found on right side of the church Source: Authors' collection. 


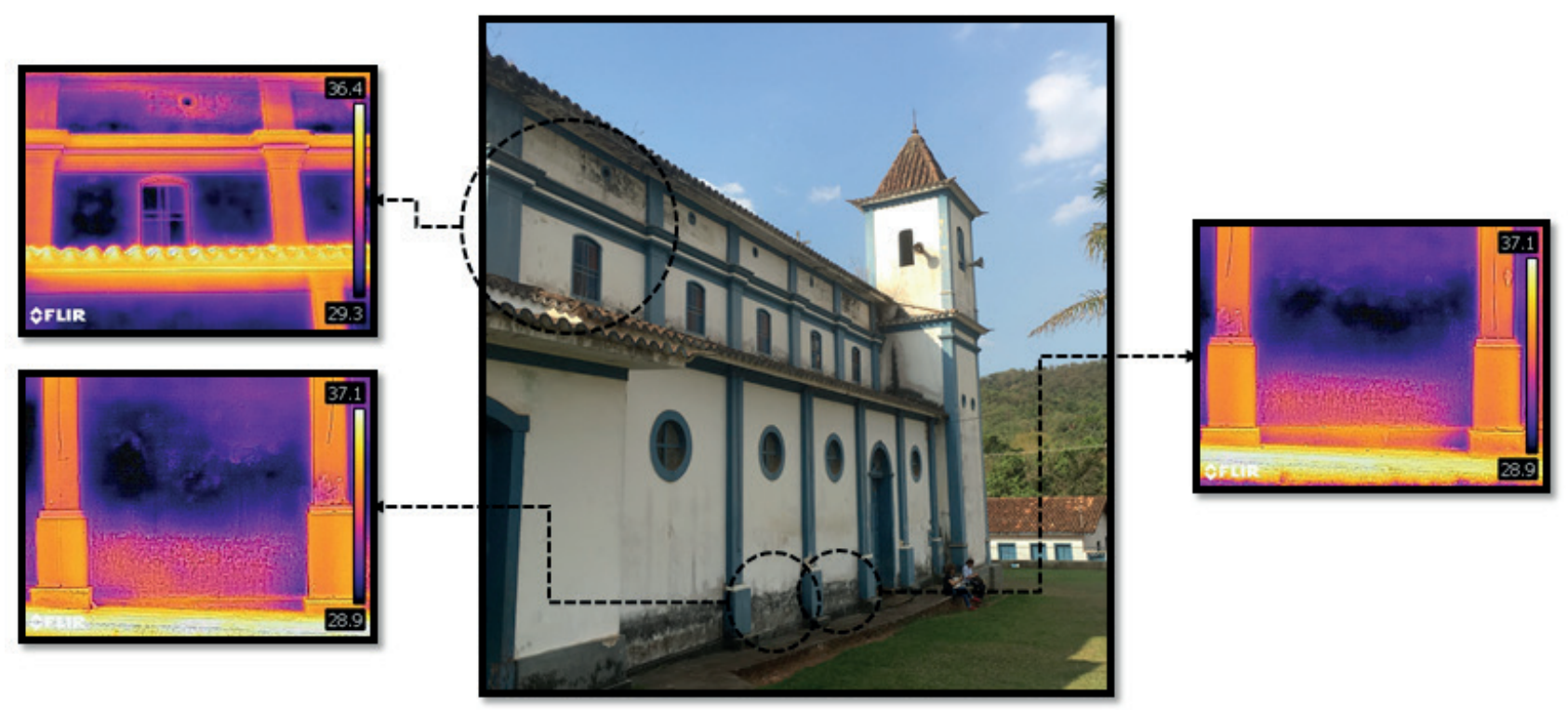

Figure 11 - Areas of moisture concentration on the left side of the church. Source: Authors' collection.

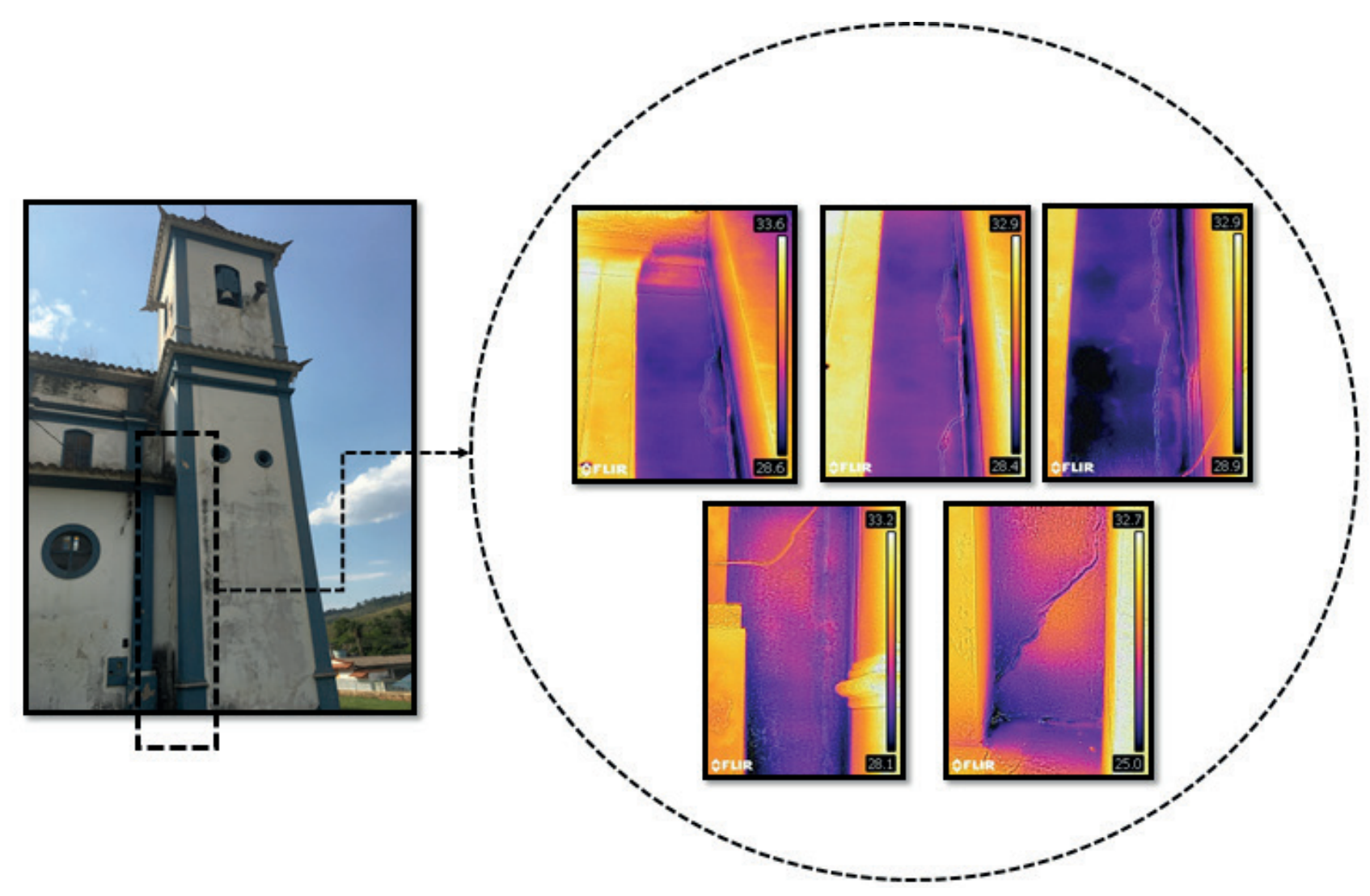

Figure 12 - Left tower of the Mother Church of Nossa Senhora da Piedade do Paraopeba Source: Authors' collection. 


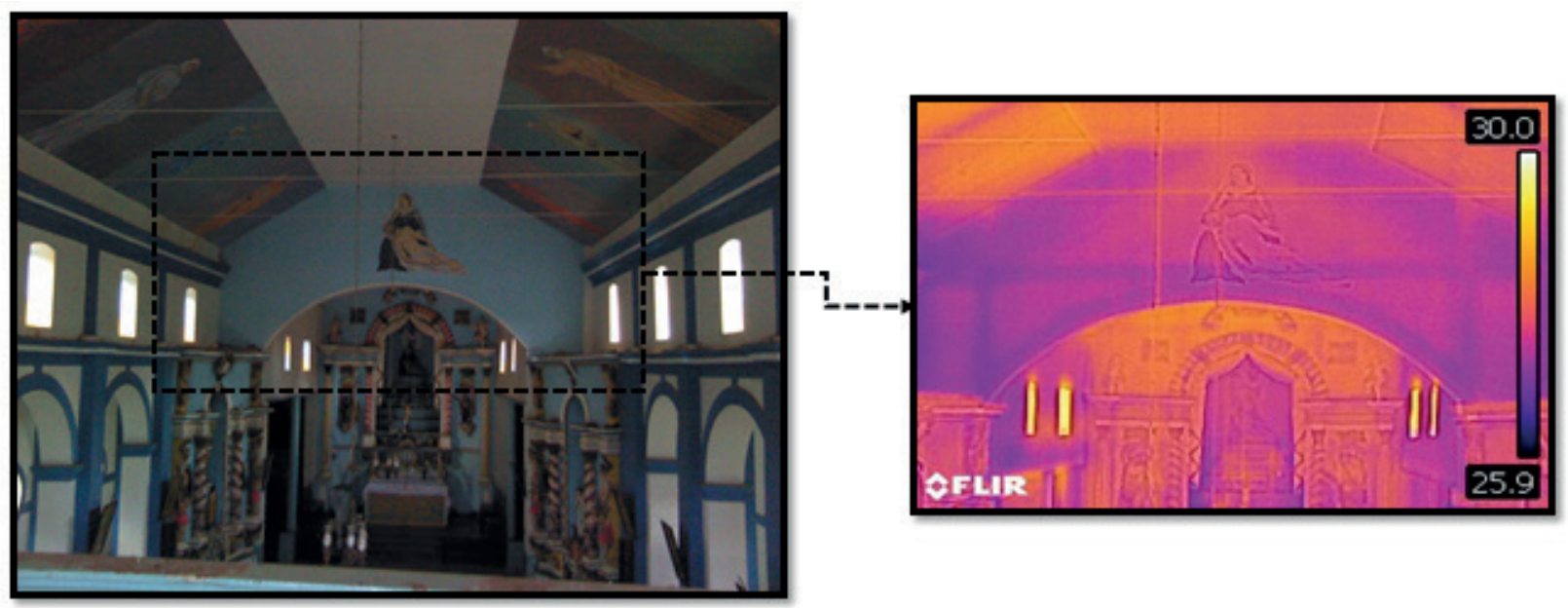

Figure 13 - Main internal arch of the Mother Church of Nossa Senhora da Piedade do Paraopeba Source: Authors' collection.
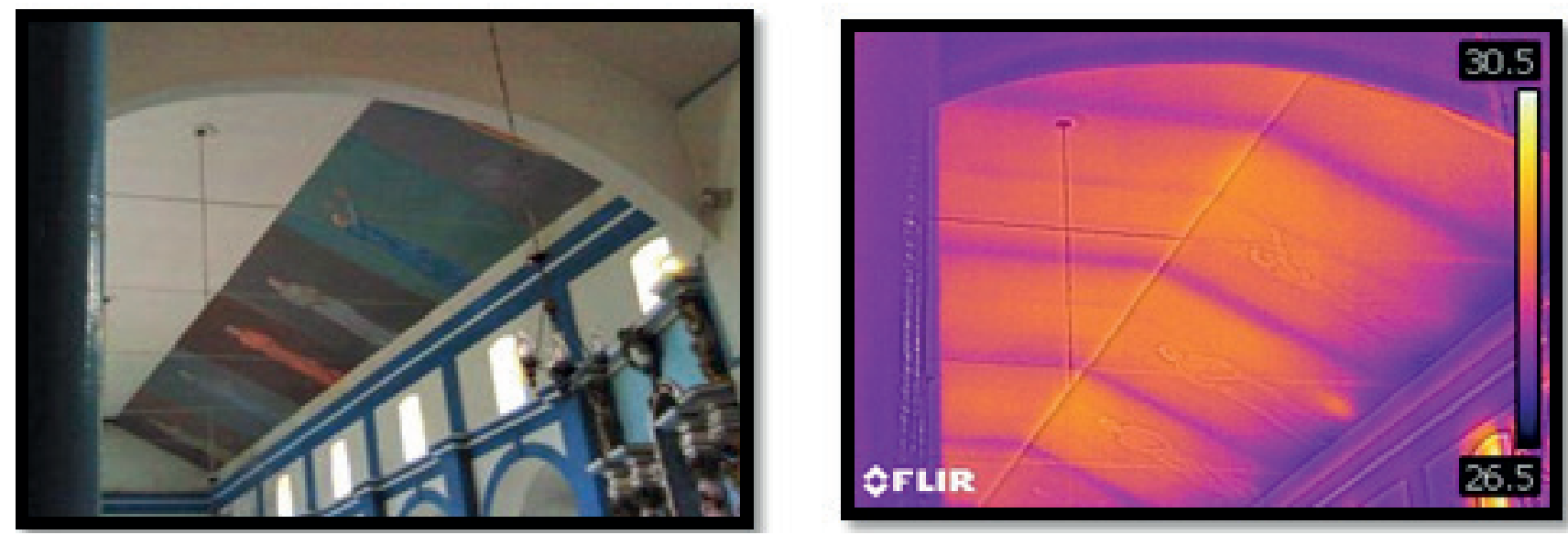

Figure 14 - Coverage in the main hall of the Mother Church of Nossa Senhora da Piedade do Paraopeba Source: Authors' collection.

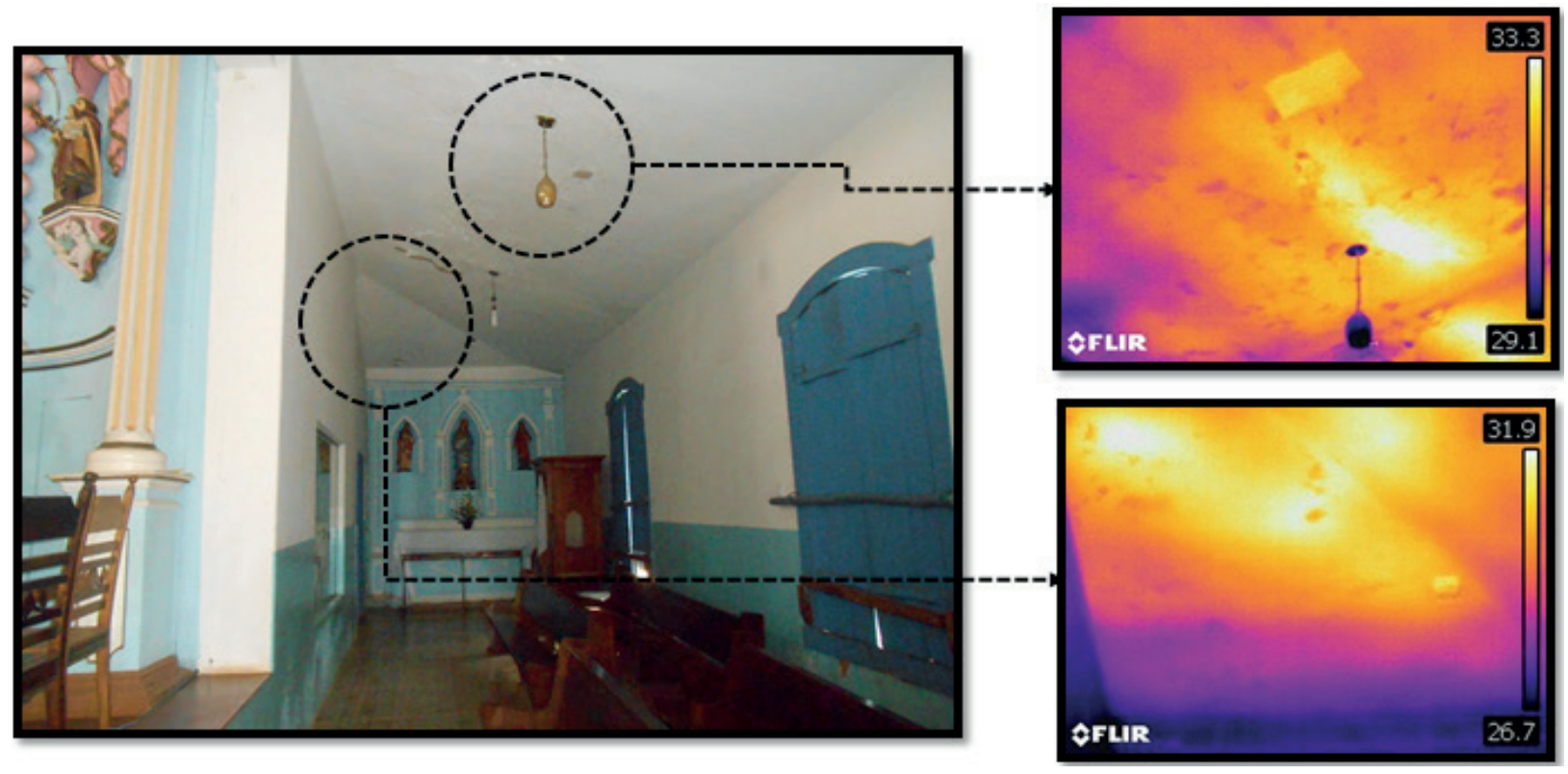

Figure 15 - Right internal corridor of the Mother Church of Nossa Senhora da Piedade do Paraopeba Source: Authors' collection. 


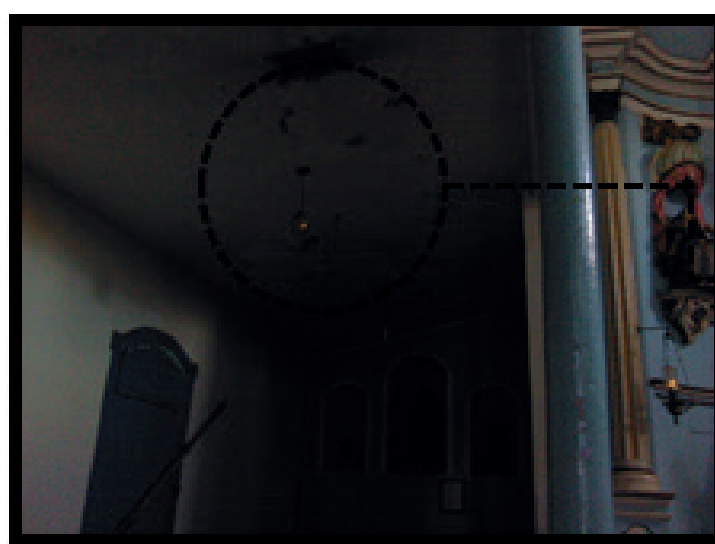

Figure 16 - Left internal corridor of the Mother Church of Nossa Senhora da Piedade Paraopeba Source: Authors' collection

\section{CONCLUSIONS}

The state of Minas Gerais has great historical and cultural value in the history of Brazil due to the presence of gold and diamond mines. The prosperity of other times resulted in several buildings that currently have great cultural and historical value. Nowadays, many historical buildings in small towns do not have adequate maintenance, being visible the action of the time and the lack of maintenance in their elements.

The preservation of the historical monuments is of paramount importance for the propagation of the customs of the time in which they were constructed. The objective of this paper was to evaluate the pathological manifestations of the Mother Church of Nossa Senhora da Piedade do Paraopeba, located in the municipality of Brumadinho, Minas Gerais, without any aesthetic damage to the property. Therefore, an analysis considering both thermal imaging camera and visual inspection was chosen.

When the research was carried out, pathological manifestations were identified due to the infiltration of water through the roof and by the absorption of water from the soil. The bad conditioning of the tiles, the lack of waterproofing, the lack of maintenance and the realization of reforms without adequate technical knowledge of the materials and techniques are the main causes of the identified pathologies. Wet spots, deterioration of mortar and paint, and detachment of the floor covering were also identified in several areas of the building.

It was concluded that the thermography test met the initial objective, confirming some of the pathological manifestations existing in the Mother Church of Nossa Senhora da Piedade do Paraopeba and identified by the visual inspection. In addition, the technique is even more suitable for use in historical heritage sites, which can not be damaged for sample removal in destructive tests and since there were large surfaces for analysis. Finally, the historical building is, in several aspects, under precarious conditions that undermine the structure and aesthetics of the whole. It is advisable to reform internal and external repair and restoration, so as to solve all the problems identified, so that the building can fulfill its role as historical patrimony, conveying the architectural and cultural value of the era in which it was built.

\section{ACKNOWLEDGEMENTS}

Acknowledgment to the parish of the Mother Church of Nossa Senhora da Piedade do Paraopeba, which granted permission for the study, to the Federal University of Minas Gerais for the availability of the equipment and the Pontifical Catholic University of Belo Horizonte.

\section{REFERÊNCIAS}

Alam, F. W., Pinz, F. P., Paliga, C. M., Torres, A. S. (2017). Metodologia de ensaio termográfico - uma análise dos parâmetros da termocâmera e seus efeitos no resultado. 59॰ Congresso Brasileiro de Concreto - 59॰ CBC, Bento Gonçalves, Brasil; November 2017.

Andrade, B. (2014). Igreja Matriz de Nossa Senhora da Piedade Distrito de Piedade do Paraopeba Brumadinho/MG - Subsídios Históricos para o Projeto de Restauração. Ouro Preto, Brasil; June 2014.

Barbosa, M. T. G. et al. (2010). Patologias de Edifícios Históricos Tombados. Encontro Nacional da Associação Nacional de Pesquisa e Pós Graduação em Arquitetura e Urbanismo - I ENAPARQ, Rio de Janeiro, Brasil; December 2010.

Bauer, E., Pavón, E. (2015). Termografia de Infravermelho na identificação e avaliação de manifestações patológicas em edifícios. Revista Concreto e Construções. 79 
(1), 93-98.

Bucur, V. (2003). Nondestructive Characterization and Imaging of Wood.

Cortizo, E. C. (2007). Avaliação da técnica de termografia infravermelha para identificação de estruturas ocultas e diagnostico de anomalias em edificações: Ênfase em Edificações do Patrimônio Histórico. Master's thesis - Federal University of Minas Gerais, Brazil.

FLIR, 2016. 3 principais aplicações da análise termográfica. http://www.flir.com.br/home/news/detail$s / ? \mid D=80767$. Access on 01/20/2018.

Grinzato, E. (2012). IR Thermography Applied to the Cultural Heritage Conservation. 18th World Conference on Nondestructive Testing. Durban, South Africa.

Instituto do Patrimônio Histórico e Artístico Nacional - IPHAN. Available in: <http://portal.jphan.gov.br/pagina/detalhes/218>. Access in: 07 November 2017.

Meinlschimidt, P. (2005). Thermographic detection of defects in wood and wood-based material. 14th International Symposium of nondestructive testing of wood. Hannover, Germany.

Nóbrega, E. S., Oliveira, J. A. C., Alves, N. J. D. (2017). Análise das manifestações patológicas em fachadas com auxílio de câmera termográfica e drone. 59० Congresso Brasileiro de Concreto - 59 $\mathrm{CBC}$, Bento Gonçalves, Brasil.

Souza, M. F. (2008). Patologias ocasionadas pela umidade nas edificações. Monografia de especialização Universidade Federal de Minas Gerais, Brasil.

Spodek, J., Rosina, E. (2009). Application of Infared Thermography to Historic Building Investigation. Journal of Architectural Conservation. 15 (1), 65-81.

Pedra, K. K. V., Carneiro, Y. S., Teixeira, G. A., Oliveira, J. A. C., Alves, N. J. D. (2017). Utilização de drone e termografia na detecção de manifestações patológicas em monumentos históricos. 59 $9^{\circ}$ Congresso Brasileiro de Concreto - $59^{\circ} \mathrm{CBC}$, Bento Gonçalves, Brasil.

Plesu, R., Teodoriu, G., Taranu, G. (2012). Infared thermography applications for building investigation. Universitatea Tehnicã "Gheorghe Asachi" din lasi Tomul LVIII, 61 (1), 157-168.

\section{AUTORES}

ORCID: 0000-0001-9510-2859

CYNARA FIEDLER BREMER, Dra. | Universidade Federal de Minas Gerais | Arquitetura e Urbanismo | Belo Horizonte, MG. Brasil | Correspondência para: Rua Paraíba, 697 - Sala 313, CEP 30130-041. Bairro Funcionários. Belo Horizonte/ MG. Brasil | Email: cynarafiedlerbremer@ufmg.br

ORCID: 0000-0002-2865-8782

GLÁUCIA NOLASCO DEALMEIDA MELLO, Dra.|Pontifícia Universidade Católica de Minas Gerais | Engenharia Civi | Belo Horizonte, MG. Brasil | Correspondência para: Rua Dom José Gaspar, 500, Prédio 3 - Sala 102, Coração Eucarístico, Belo Horizonte MG - Brasil - CEP 30535-901 | Email: gnamello@pucminas.br

ORCID: 0000-0002-5371-8193

FERNANDA ISABELLA SOARES BERNARDES| Pontifícia Universidade Católica de Minas Gerais | Engenharia Civil e Arquitetura e Urbanismo | Belo Horizonte, MG. Brasil | Correspondência para: Rua Doutor José Greco, 66, Belo Horizonte - MG - Brasil - CEP 30360-030 | Email: fernandaisbernardes@gmail.com

ORCID: 0000-0002-7783-691X

MARCELLA AMARAL RODRIGUES PINTO | Pontifícia Universidade Católica de Minas Gerais|Especialista em Avaliações e Perícias de Engenharia | Belo Horizonte, MG. Brasil | Correspondência para: Rua Martim Afonso, 1168/Apt 105, Bigorrilho - Curitiba/ PR 80730-030 | Email: marcellamarp@yahoo.com.br

ORCID: 0000-0003-2546-8649

ALINE MARACAHIPE ROCHA | Universidade Federal de Minas Gerais | Arquitetura e Urbanismo | Belo Horizonte, MG. Brasil | Correspondência para: Rua Paraíba, 697 - Sala 313, CEP 30130-041. Bairro Funcionários. Belo Horizonte/MG. Brasil | Email: alinemaracahipe@gmail.com

\section{COMO CITAR ESTE ARTIGO}

BREMER, Cynara Fiedler; MELLO, Gláucia Nolasco de Almeida; BERNARDES, Fernanda Isabella Soares; PINTO, Marcella Amaral Rodrigues; ROCHA, Aline Maracahipe. Análise das Manifestações Patológicas na Igreja de Nossa Senhora da Piedade do Paraopeba Usando Termografia.

MIX Sustentável, [S.I.], v. 5, n. 4, p. 125-136, out. 2019. ISSN 24473073. Disponível em:<http://www.nexos.ufsc. br/index.php/mixsustentavel>. Acesso em: dia mês. ano. doi:https://doi.org/10.29183/2447-3073.MIX2019. v5.n4.125-136.

DATA DE ENVIO: 02/10/2019 